\title{
Pengaruh Belanja Hibah, Belanja Bantuan Sosial, Belanja Bantuan Keuangan, dan Belanja Fasilitas Umum Terhadap Keterpilihan Petahana dalam Pemilukada 2017
}

\author{
Ummu Auliyah $^{1 *}$, Suhairi $^{2}$, Nini Syofri Yeni ${ }^{3}$ \\ ${ }^{1,2,3}$ Fakultas Ekonomi Pascasarjana Akuntansi, Universitas Andalas, Indonesia \\ *Correspondence email: ummuauliyah@gmail.com
}

\begin{abstract}
This study aims to determine the effect of grant expenditure, social assistance expenditure, financial aid expenditure and public facility expenditure on incumbent election in the General Election of Regional Head conducted in 2017. The type of this research is quantitative descriptive research. The objects examined are grant expenditure, social assistance expenditure, financial aid expenditure, and public facility expenditure in the 2015-2016 regional budget. The year 2015 represented shopping data prior to the General Election of Regional Head, while 2016 represented spending data at the time of the General Election of Regional Head. This study uses a logistic regression statistical test. The data analysis tool used for hypothesis testing is the Wald test. The results of this study state that there is no relationship between the independent variable and the dependent variable, but almost all regions have an increase in grant expenditure, financial aid expenditure, and public facilities ahead of the implementation of the General Election, while the average social assistance expenditure has decreased.
\end{abstract}

Keyword: Grant Expenditure, Social Aid Expenditure, Financial Aid Expenditure, Public Facility Expenditures, Incumbent

\section{PENDAHULUAN}

Indonesia memiliki 416 kabupaten dan 98 kota yang tersebar dari Sabang sampai Merauke. Di setiap daerah pemerintahan dipimpin oleh seorang kepala daerah yang bertugas sebagai pemimpin dalam melaksanakan segala urusan pemerintahan. Kepala daerah dipilih oleh masyarakat untuk jangka waktu 5 (lima) tahun kedepan. Menurut Undang-Undang Nomor 1 Tahun 2004 tentang pemilihan Gubernur, Bupati, dan Walikota disebutkan bahwa kepala daerah dapat dipilih kembali untuk jabatan yang sama hanya untuk satu kali masa jabatan. Hal tersebut juga berarti, bahwa seseorang yang menjadi Kepala Daerah, boleh memangku jabatan yang sama pada suatu Daerah hanya untuk 2 (dua) kali periode atau maksimal selama 10 (sepuluh) tahun. Kepala daerah yang mendaftar kembali untuk mengikuti pemilihan berikutnya disebut sebagai incumbent atau petahana. Petahana menurut KBBI (Kamus Besar Bahasa Indonesia) adalah pemegang suatu jabatan tertentu (yang sedang atau masih menjabat). Petahana memiliki peluang besar untuk memenangkan pemilihan umum kepala Daerah berikutnya jika dia dianggap sukses atau memiliki kinerja yang efektif dan efisien dalam menjalankan tugasnya oleh masyarakat dalam memimpin Daerah pada periode pertama.

Memasuki masa pemilukada, biasanya petahana melakukan berbagai cara agar dapat menarik perhatian pemilih sehingga petahana dapat memenangkan kembali pemilihan Kepala Daerah pada periode berikutnya. Menurut Matz dan Eva, 1999 (dalam Habibi, Kalalinggi, dan Alaydrus 2017), pada masa pemilihan kepala daerah, petahana cenderung melakukan suap politik yaitu melakukan pembelian suara serta mengambil berbagai macam belanja dan hibah untuk menutup pengeluaran kampanye yang sangat besar. Walikota dan Bupati memiliki otonomi yang berbeda dengan Presiden sehingga salah satu celah yang dapat dimanfaatkan oleh Walikota dan Bupati untuk menarik perhatian masyarakat atau calon pemilih adalah dengan memberikan bantuan langsung kepada masyarakat serta perbaikan fasilitas yang ada didaerah. Salah satunya adalah dengan membangun atau meningkatkan fasilitas umum yang ada di daerah tersebut.

Habibi, dkk (2018) melakukan penelitian yang berjudul politik anggaran belanja hibah dan belanja bantuan sosial calon kepala daerah incumbent dalam pemilihan umum Kepala daerah tahun 2015 di Samarinda. Dalam penelitian ini dijelaskan bahwa adanya pemanfaatan belanja hibah dan belanja bantuan sosial oleh petahana untuk menarik minat pemilih agar dapat dipilih kembali di pemilihan berikutnya. Salah satu komponen anggaran belanja yang juga dapat menarik perhatian masyarakat dalam dalam menilai kesuksesan seorang petahana adalah anggaran belanja fasilitas umum, karena output atau hasil dari kegiatan belanja tersebut dapat dirasakan dan dinikmati langsung oleh masyarakat, misalnya perbaikan jalan disekitar pemukiman warga, irigasi dan pembangunan fasilitas kesehatan. Penelitian ini bertujuan untuk mengetahui pengaruh belanja hibah, belanja bantuan sosial, belanja bantuan keuangan, dan belanja fasilitas umum terhadap keterpilihan petahana dalam pemilukada 2017. 


\section{Landasan Teori}

\section{Teori Agensi}

Teori agensi pertama kali diperkenalkan oleh Jansen dan Meckling pada tahun 1976. Teori agensi menjelaskan hubungan prinsipal dan agen ini salah satunya berakar pada teori ekonomi, teori keputusan, sosiologi, dan teori organisasi. Teori keagenan menganalisis susunan kontraktual diantara dua atau lebih individu, kelompok, atau organisasi. Hubungan prinsipal-agen terjadi apabila tindakan yang dilakukan seseorang memiliki dampak pada orang lain atau ketika seseorang sangat tergantung pada tindakan orang lain (Stiglitz, 1987 dan Pratt \& Zeckhauser, 1985 dalam Halim \& Abdullah, 2006). Dalam pemerintahan terdapat hubungan keagenan, khususnya hubungan antara eksekutif dan legislatif yang ada pada pemerintahan yang pada kenyataannya saling menguntungkan. Menurut Subaweh (2008) agensi teori merupakan hubungan antara principal dan agent, dimana principal bertugas memberi wewenang sedangkan agent bertugas menerima wewenang. Principal dalam pemerintahan daerah adalah pihak legislatif yaitu DPRD sedangkan agent adalah pihak eksekutif yaitu kepala daerah. Penerapan teori agency dalam pemerintahan daerah seringkali menyebabkan asimentri informasi antara principal dan agent. Namun asimetri informasi antara eksekutif dan legislatif akan terkikis jika legislatif memanfaatkan discretionary powernya dalam penganggaran (Abdullah \& Asmara, 2006).

\section{Moral Hazard}

Moral Hazard secara etimologis berarti jebakan moral. Menurut Nyman (2004) menyebut persepsi yang buruk terhadap resiko ini disebut sebagai "Morale Hazard" yang dideskripsikan sebagai carelessness or indifference to a loss (kecerobohan atau ketidakpedulian terhadap kerugian). Moral Hazard dikemukakan pertama kali oleh Pauly (1968). Pauly mengemukakan bahwa moral hazard sangat besar pengaruhnya di bidang pelayanan kesehatan. Moral hazard diduga membuat orang berubah perilakunya ketika mereka telah dijamin oleh asuransi dibandingkan sebelum dijamin. Moral hazard merupakan perilaku tidak jujur dalam memberikan informasi kepada pihak lain yang membuat kontrak kerjasama, demi memenuhi keinginannya (Dowd, 2008). Moral hazard dalam konteks teori keagenan terjadi karena ada asimetri informasi antara prinsipal (pemilik, pemegang saham) dengan agen (manager). Asimetri informasi merupakan ketidakseimbangan informasi antara pihak yang dapat memperoleh dan memanfaatkan informasi untuk kepentingannya dengan pihak lain yang tidak dapat memperoleh informasi yang sama (Scott, 2000).

\section{Anggaran Pendapatan dan Belanja Daerah}

Menurut Bastian (2010) pengertian APBD adalah "Anggaran Pendapatan dan Belanja Daerah merupakan pertanggungjawaban rencana kerja Pemerintah Daerah dalam bentuk suatu uang untuk kurun waktu satu tahun dan berorientasi pada tujuan kesejahteraan publik". Menurut Halim (2012: 10): "Anggaran Pendapatan dan Belanja Daerah (APBD) adalah rencana keuangan pemerintah daerah yang dibahas dan disetujui bersama oleh Pemerintah Daerah dan DPRD". Dalam Permendagri No 21 Tahun 2011 disebutkan bahwa Anggaran Pendapatan dan Belanja Daerah (APBD) adalah rencana keuangan tahunan pemerintah daerah yang dibahas dan disetujui bersama oleh pemerintah daerah dan Dewan Perwakilan Rakyat Daerah (DPRD) dan ditetapkan dengan Peraturan Daerah.

1) Belanja hibah

Menurut Peraturan Menteri Dalam Negeri (Permendagri) Nomor 14 Tahun 2016 dijelaskan bahwa hibah adalah pemberian uang/barang atau jasa dari pemerintah daerah kepada pemerintah pusat atau pemerintah daerah lain, Badan Usaha Milik Daerah, badan, lembaga dan organisasi kemasyarakatan yang berbadan hukum Indonesia. Pemberian hibah dilakukan untuk menunjang pencapaian sasaran program dan kegiatan pemerintah daerah sesuai dengan urgensi dan kepentingan daerah dalam mendukung terselenggaranya fungsi pemerintahan, pembangunan dan kemasyarakatan dan memperhatikan asas keadilan, kepatuhan, rasionalitas dan manfaat untuk masyarakat.

2) Belanja bantuan sosial

Bantuan sosial dalam Permendagri No 14 Tahun 2016 disebutkan adalah pemberian bantuan berupa uang/barang dari pemerintah daerah kepada individu, keluarga, kelompok dan/atau masyarakat yang sifatnya tidak secara terusmenerus dan selektif yang bertujuan untuk melindungi dari kemungkinan terjadinya resiko sosial. Resiko sosial merupakan suatu kondisi yang dapat menimbulkan potensi terjadinya kerentanan sosial yang ditanggung oleh individu, keluarga, kelompok dan/atau masyarakat. Pemberian bantuan ini tidak wajib sehingga tidak harus diberikan tiap tahun anggaran. Khusus untuk partai politik, bantuan yang diberikan sesuai dengan ketentuan peraturan perundang-undangan yang dianggarkan dalam bantuan sosial.

3) Belanja bantuan keuangan

Belanja bantuan keuangan merupakan dana yang diterima dari daerah lainnya baik dalam rangka kerjasama daerah, pemerataan, peningkatan kemampuan keuangan, dan/atau tujuan tertentu lainnya dari pemerintah provinsi atau pemerintah kabupaten/kota lainnya. Menurut Peraturan Menteri Dalam Negeri No 33 Tahun 2017 tentang Pedoman Penyusunan APBD, bahwa belanja bantuan keuangan harus didasarkan untuk mengatasi kesenjangan 
fiskal. Kemudian, membantu pelaksanaan urusan pemerintah daerah yang tidak tersedia alokasi dananya dan/atau menerima manfaat dari pemberian bantuan keuangan tersebut, serta dalam rangka kerjasama antar daerah sesuai kemampuan keuangan masing-masing daerah

4) Belanja fasilitas umum

Belanja fasilitas umum merupakan belanja yang digunakan untuk membiayai penyelenggaraan penyediaan perumahan dan fasilitas umum yang menjadi tanggungjawab pemerintah. Belanja modal fasilitas umum dialokasikan untuk pembangunan gedung sekolah, puskesmas, jembatan, rumah sakit, jalan, dan irigasi. Dalam Peraturan Menteri Keuangan Nomor 112 Tahun 2015 tentang klasifikasi anggaran dijelaskan bahwa fungsi pembelanjaan digunakan untuk pengembangan perumahan, pemberdayaan komunitas fasilitas umum, penyediaan air minum, penerangan jalan, litbang (penelitian dan pengembangan) dan perumahan dan fasilitas umum lainnya.

\section{Pemilukada}

Pengertian Pemilukada (pemilihan umum kepala daerah) menurut Undang-Undang Nomor 22 Tahun 2007 mengenai penyelenggaraan pemilihan umum dimana pemilukada merupakan proses pemilihan kepala daerah dan wakil kepala daerah secara langsung oleh Warga Negara Indonesia dalam Negara Kesatuan Republik Indonesia berdasarkan Pancasila dan UUD 1945. Pemilukada dilaksanakan setiap lima tahun sekali dan kepala daerah dapat menempati jabatan yang sama untuk dua periode. Menurut Undang-Undang Nomor 8 Tahun 2015 Pemilihan Umum Kepala Daerah dan Wakil Kepala Daerah (Pemilukada) adalah pelaksanaan kedaulatan rakyat di wilayah provinsi dan kabupaten/kota untuk memilih Gubernur dan Wakil Gubernur, Bupati dan Wakil Bupati, serta Walikota dan Wakil Walikota secara langsung dan demokratis.

\section{Petahana dan Bukan Petahana}

Undang-Undang Nomor 10 Tahun 2016 Pasal 41 menyebutkan bahwa setiap kepala daerah diberikan batasan selama dua periode untuk melaksanakan tugasnya di daerah. Pembatasan periode ini dilakukan untuk menghindari adanya pemerintahan yang bersifat otoriter. Kata petahana dalam Kamus Besar Bahasa Indonesia (KBBI) edisi IV terbitan 2008 menyatakan bahwa petahana berasal dari kata "tahana" yang bermakna "kedudukan, martabat (kebesaran, kemuliaan, dan sebagainya)". Kata petahana pertama kali diperkenalkan oleh Salomo Simanungkalit pada 6 Februari 2009, alasan kata ini baru dibutuhkan karena presiden sebelumnya tidak memiliki penantang

\section{Hipotesis}

Adanya pemilukada tahun 2017 menjadi salah satu celah bagi para petahana dalam memanfaatkan dana APBD, alokasi belanja hibah sebelum dan pada saat pemilukada sangat penting untuk diukur kembali untuk melihat perkembangan jumlah belanja hibah yang ada di pemerintah daerah. Penelitian yang dilakukan oleh Ritonga \& Alam (2010) mengungkapkan adanya petahana yang memanfaatkan Anggaran Pendapatan dan Belanja Daerah (APBD) untuk pencalonannya kembali sebagai kepala daerah. Adanya temuan bahwa proporsi belanja hibah daerah pada saat pemilukada di daerah petahana lebih besar daripada proporsi belanja hibah daerah pemilukada bukan petahana. Indonesian Corruption Watch (ICW) bekerja sama dengan Universitas Murdoch (Kompas 14/4 2009) juga melakukan penelitian, hasilnya yaitu terdapat peningkatan alokasi belanja hibah dan bantuan sosial dalam APBD pada saat pelaksanaan pemilukada tahun 2008 di Kabupaten Tabanan (Bali), Kota Bau-Bau (Sulawesi Tenggara), dan Kota Bandung (Jawa Barat).

H1:Kenaikan belanja hibah berpengaruh terhadap keterpilihan petahana pada Pemilukada tahun 2017

Belanja bantuan sosial merupakan bantuan yang diberikan pemerintah daerah dan bersifat sosial kemasyarakatan dalam bentuk uang dan/atau barang kepada kelompok/anggota masyarakat, dan partai politik. Bantuan yang diberikan tersebut tidak mengikat/tidak terus-menerus. Dalam penelitian Amalia \& Pratolo (2013) menyatakan bahwa terdapat adanya kemungkinan pemanfaatan belanja bantuan sosial oleh petahana menjelang Pemilukada demi kepentingan politisnya. Penelitian Habibi, Kalalinggi, \& Alaydrus (2018) juga menyimpulkan bahwa adanya indikasi dari para petahana dengan berusaha tetap memberikan bantuan agar menarik minat pemilih dalam pemilukada 2015

H2:Kenaikan belanja bantuan sosial berpengaruh terhadap keterpilihan petahana pada Pemilukada tahun 2017

Peraturan Menteri Dalam Negeri Nomor 13 Tahun 2006 mengatakan bahwa bantuan keuangan digunakan untuk menganggarkan bantuan keuangan yang bersifat umum atau khusus dari provinsi kepada kabupaten/kota kepada pemerintah desa dan pemerintah daerah lainnya atau dari pemerintah kabupaten/kota kepada pemerintah desa dan pemerintah daerah lainnya. Bantuan ini bersifat umum dan diserahkan sepenuhnya kepada pemerintah daerah/pemerintah desa penerima bantuan. Penelitian yang dilakukan Martha (2016) mengungkapkan adanya perbedaan proporsi anggaran sebelum dengan pada saat pemilukada. Pada saat pemilukada proporsi belanja bantuan keuangan lebih besar dibandingkan proporsi belanja keuangan sebelum pemilukada. Handayani (2010) dalam 
penelitian juga membuktikan adanya perbedaan alokasi belanja kabupaten/kota yang petahananya tidak mengikuti pemilukada berikutnya dibandingkan petahana yang mengikuti pemilukada berikutnya

H3:Kenaikan belanja bantuan keuangan berpengaruh terhadap keterpilihan petahana pada Pemilukada 2017

Salah satu cara petahana mempertahankan kekuasaannya adalah dengan memperlihatkan kepada masyarakat perubahan yang berhasil atau telah dilakukan. Semakin banyak perubahan yang ada di daerah tersebut menjadikan masyarakat lebih yakin untuk memilih kembali petahana. Salah satu perubahan tersebut dapat dilihat dari belanja fasilitas umum yang dikeluarkan oleh petahana selama menjabat. Pada laporan hasil pemeriksaan BPK terhadap pengelolaan anggaran belanja modal untuk fasilitas umum daerah ditemukan penyimpangan anggaran belanja modal di daerah dengan kerugian sebesar Rp 726,4 miliar. Belanja modal fasilitas umum itu dialokasikan untuk pembangunan gedung sekolah, puskesmas, jembatan, rumah sakit, jalan hingga irigasi. Menurut Forum Indonesia untuk Transparansi Anggaran (FITRA) terdapat 1.309 temuan penyimpangan pengelolaan anggaran di sejumlah daerah.

H4: Kenaikan belanja fasilitas umum berpengaruh terhadap keterpilihan petahana pada Pemilukada 2017

\section{METODE}

Desain penelitian yang digunakan adalah deskriptif kuantitatif. Pendekatan dalam tujuan penelitian (purpose of study) ini adalah pengujian hipotesis (hypothesis testing). Model analisis yang dipakai adalah analisis regresi logistik. Data yang digunakan dalam penelitian ini adalah data dokumenter, yaitu data yang berupa laporan keuangan tahunan yang telah diaudit dan dipublikasi oleh kementerian keuangan Republik Indonesia. Sedangkan sumber data dalam penelitian ini adalah data sekunder, dalam penelitian ini diperoleh dari sejumlah data atau dokumen yang berasal dari tangan kedua atau lebih yang berkaitan terhadap objek penelitian. Data pada penelitian ini adalah laporan keuangan yang telah diaudit, yaitu daerah kabupaten/kota. Data penelitian ini menggunakan Laporan Keuangan Pemerintah Daerah (LKPD) yang telah diaudit oleh BPK serta laporan dari BPS. Sedangkan data pemerintah daerah yang mengikuti Pemilukada pada tahun 2017 diperoleh dari website KPU. Populasi dalam penelitian ini adalah Daerah Kabupaten/Kota yang melaksanakan pemilukada pada tahun 2017. Penelitian ini menggunakan teknik purposive sampling dalam pengambilan sampel, yaitu kabupaten/kota yang mengikuti pemilukada pada tahun 2017. Pengambilan sampel pada penelitian ini mengajukan dua kriteria pemilihan sampel, yaitu: (1) Daerah kabupaten/kota yang melaksanakan pemilukada pada tahun 2017; (2) Data alokasi belanja hibah dan belanja bantuan sosial,belanja bantuan keuangan dan belanja fasilitas umum dalam APBD kabupaten/kota tahun 2015-2016 yang bersumber dari Direktorat Jendral Perimbangan Keuangan Kementrian Keuangan Republik Indonesia dan pemerintah daerah kabupaten/kota. Dalam penelitian ini, metode pengumpulan data yang diperoleh dengan cara mengakses situs-situs terkait dengan penelitian ini yaitu www.kpu.go.id, https://pilkada2017.kpu.id.id yang merupakan situs resmi Komisi Pemilihan Umum, www.bps.go.id yang merupakan situs resmi Badan Pusat Statistik, serta www.djpk.depkeu.go.id yang merupakan situs resmi Direktorat Jendral Perimbangan Keuangan Kementrian Keuangan sebagai sumber data keuangan daerah. Metode pengumpulan data juga dengan mempelajari berbagai literatur dan juga jurnal-jurnal penelitian terdahulu yang berkaitan. Proses penetapan sampel dengan menggabungkan data terkait melalui situs-situs resmi yang telah disebutkan sebelumnya.

\section{HASIL}

Populasi dalam penelitian ini adalah pemerintah daerah yang mengikuti Pemilukada pada tahun 2017 dengan periode penelitian yang diambil pada tahun 2015 mewakili data sebelum Pemilukada, dan 2016 mewakili data pada saat Pemilukada. Pemilihan pemerintah daerah tersebut sebagai objek dalam penelitian ini karena daerah tersebut mengikuti Pemilukada pada tahun yang sama sehingga diharapkan dapat memberikan data yang lebih baik dan menggambarkan kondisi ekonomi yang sama. Data pemerintah daerah sampel peroleh dengan mendownload data realisasi laporan keuangan pemerintah daerah dan data realisasi belanja perfungsi pada situs www.djpk.kemenkeu.go.iddan www.bps.go.id. Berdasarkan tabel uji pengaruh variabel secara parsial belanja bantuan hibah tidak berpengaruh terhadap keterpilihan petahana pada Pemilukada tahun 2017. Hasil penelitian ini tidak sesuai dengan hasil penelitian yang dilakukan oleh Ritonga dan Alam (2010), Dian Martha (2016). Dimana hal ini menunjukkan bahwa variabel terikat yang digunakan dalam penelitian berhubungan dengan variabel bebasnya. Hal ini dibuktikan dengan besarnya biaya yang dikeluarkan untuk belanja hibah untuk tahun 2016 dibandingkan tahun 2015 .

Menurut hasil penelitian Ritonga dan Alam (2010) membuktikan bahwa hasil penelitian tersebut membuktikan bahwa terdapat kemungkinan pemanfaatan belanja hibah oleh petahana agar dapat memenangkan Pemilukada berikutnya. Dalam penelitian Martha (2016) juga disebutkan bahwa proporsi anggaran belanja hibah pada saat pelaksanaan Pemilukada lebih besar daripada proporsi anggaran belanja hibah sebelum pelaksanaan Pemilukada

H1: Belanja hibah tidak berpengaruh terhadap keterpilihan petahana pada Pemilukada 2017 
Berdasarkan tabel uji pengaruh variabel belanja bantuan sosial tidak berpengaruh secara signifikan terhadap keterpilihan petahana pada Pemilukada tahun 2017.Hasil pengujian ini gagal menemukan adanya pengaruh signifikan disebabkan karena belanja bantuan sosial yang tercatat pada tahun 2015 lebih besar dibandingkan belanja bantuan sosial pada tahun 2016. Belanja bantuan sosial diberikan tidak secara terus menerus dan penggunaannya mempertimbangkan kemampuan keuangan keuangan daerah.Sehingga pos belanja bantuan sosial mungkin tidak menjadi pilihan oleh kepala daerah menjelang Pemilukada.

H2: Belanja bantuan sosial tidak berpengaruh terhadap keterpilihan petahana pada Pemilukada 2017

Pengujian regresi logistik menunjukkan bahwa tidak terdapat pengaruh belanja bantuan keuangan terhadap keterpilihan petahana dalam Pemilukada 2017. Hal ini tidak sesuai dengan penelitian yang dilakukan Amalia dan Pratolo (2013) serta Yuwani (2011).Tidak adanya pengaruh belanja bantuan keuangan terhadap keterpilihan petahana menyatakan bahwa kepala daerah tidak menggunakan pos belanja ini demi kepentingan pribadinya menjelang Pemilukada.

\section{H3: Belanja bantuan keuangan tidak berpengaruh terhadap keterpilihan petahana pada Pemilukada 2017}

Belanja fasilitas umum tidak memiliki pengaruh terhadap keterpilihan petahana dalam Pemilukada 2017. Bila dilihat dari dana belanja fasillitas umum dapat ditarik kesimpulan bahwa hampir diseluruh wilayah yang mengikuti Pemilukada mengalami kenaikan untuk belanja fasilitas umum pada tahun 2016. Kenaikan tersebut merata bahkan untuk daerah yang untuk Pemilukada 2017 tidak diikuti oleh petahana itu sendiri. Tidak berpengaruhnya belanja fasilitas umum terhadap kenaikan petahana menjadikan bukti bahwa kepala daerah yang menjabat menggunakan pos tersebut untuk meningkatkan sarana dan prasarana agar pelayanan pemerintah daerah menjadi lebih baik.

H3: Belanja fasilitas umum tidak berpengaruh terhadap keterpilihan petahana pada Pemilukada 2017

Hasil penelitian dijelaskan bahwa semua variabel tidak berkaitan dengan kemenangan petahana dalam Pemilukada yang dilaksanakan pada tahun 2017. Beberapa alasan yang mungkin terjadi adalah:

1. Pada sampel yang diuji bila dilihat secara nominal, pada pos belanja hibah, belanja bantuan keuangan, dan belanja fasilitas umum secara rata-rata mengalami kenaikan hampir dikeseluruhan daerah.

2. Kenaikan belanja fasilitas umum terjadi di hampir seluruh wilayah yang menjadi sampel pada penelitian ini. Hal ini terjadi mungkin karena adanya imbauan dari pemerintah pusat terkait penggunaan belanja modal yang terus ditingkatkan sebesar 30\%. Penambahan persentase tersebut telah dilakukan oleh pemerintah daerah secara bertahap sebelum tahun 2013. Menurut Mendagri yang saat itu dijabat oleh Gamawan Fauzi agar menjadi lebih efisiensi dan APBD menjadi semakin sehat.

3. Apabila dilihat secara lebih lanjut, pada Pulau Sumatera, Jawa, Kalimantan, dan Bali keterpilihan petahana tidak memiliki pengaruh terhadap pos-pos belanja hibah, belanja bantuan sosial, belanja bantuan keuangan dan belanja fasilitas umum. Namun pada Pulau Sulawesi, Nusa Tenggara, Maluku, dan Papua pos-pos belanja tersebut memiliki pengaruh terhadap keterpilihan petahana pada Pemilukada 2017.

Tabel 1

Keterpilihan Petahan pada Pemilukada 2017

\begin{tabular}{|c|c|c|c|c|c|}
\hline Wilayah & Overall & Hibah & Bansos & Bankeu & Fasum \\
\hline Barat & 0,204 & 0,298 & 0,263 & 0,759 & 0,517 \\
\hline Timur & 0,033 & 0,111 & 0,093 & 0,314 & 0,032 \\
\hline
\end{tabular}

Sumber: data olahan

Melihat dari tabel diatas maka dapat diambil kesimpulan bahwa wilayah barat Indonesia tidak memiliki pengaruh terhadap keterpilihan petahana. Hasil olahan diatas dapat dilihat bahwa baik secara keseluruhan maupun secara parsial variabel independen tidak berpengaruh terhadap variabel dependen. Hal ini diduga karena lebih berkembangnya sumber informasi yang ada di masyarakat, tingginya ilmu pengetahuan masyarakat, tingkat kesadaran masyarakat yang lebih baik

4. Tidak berpengaruhnya variabel independen dengan variabel dependen diduga berhubungan mematuhi peraturan dan adanya kekhawatiran pemerintah daerah terkait pengawasan laporan keuangan yang dilakukan oleh instansi pengawas baik yang dilakukan oleh Inspektorat, BPKP (Badan Pengawas Keuangan dan Pembangunan), BPK (Badan Pengawas Keuangan), dan instansi pengawas lainnya.

\section{SIMPULAN}

1. Berdasarkan uji regresi logistik dapat disimpukan bahwa proporsi belanja hibah tidak berpengaruh signifikan terhadap keterpilihan petahana pada Pemilukada 2017.

2. Proporsi belanja bantuan sosial tidak berpengaruh terhadap keterpilihan petahana pada Pemilukada 2017.

3. Proporsi belanja bantuan keuangan tidak berpengaruh terhadap keterpilihan petahana pada Pemilukada 2017.

4. Proporsi belanja fasilitas umum tidak berpengaruh terhadap keterpilihan petahana pada Pemilukada 2017. 
Ummu Auliyah et al, Pengaruh Belanja Hibah, Belanja Bantuan Sosial, Belanja Bantuan Keuangan, dan Belanja Fasilitas Umum Terhadap Keterpilihan Petahana dalam Pemilukada 2017

\section{DAFTAR PUSTAKA}

Alvian. 2018. Analisis Pola Belanja Hibah, Belanja Bantuan Sosial, Belanja Barang dan Jasa, dan Belanja Modal Sebelum dan Pasca Pemilukada pada Kepala Daerah Incumbent. Universitas Islam Indonesia

Amalia, Pratolo. 2013. Analisis Terhadap Dugaan Pemanfaatan Belanja Hibah, Belanja Bantuan Sosial, dan Belanja Bantuan Keuangan oleh Incumbent dalam Pemilukada serta Efektifitasnya Terhadap Pendapatan Asli Daerah. Jurnal Akuntansi \& Investasi Vol. 14

ANS,https://tesisdisertasi.blogspot.com/2015/05/analisis-regresi-logistik.html diakses pada September 2019

Dahlberg, M., Johansson, E. (2002). On the Vote-Purchasing Behavior of Incumbent Governments. The American Political Science Review, 96 (1) 27-40

Habibi, Muhammad,. Kalalinggi, Rita, dan Alaydrus, Anwar. 2017. Politik Anggaran Belanja Hibah dan Belanja Bantuan Sosial Calon Kepala Daerah Non-incumbent dalam Pemilihan Umum Kepala Daerah Tahun 2015 di Kota Samarinda. eJournal Ilmu Pemerintahan. Universitas Mulawarman

Halim dan Abdullah, S. 2006. Hubungan dan masalah keagenan di pemerintahan derah: Sebuah Peluang Penelitian Anggaran dan Akuntansi. Jurnal Akuntansi Pemerintah 2(1): 53-64. http:www.bppk.depkeu.go.id

Jensen, M C and Meckling, W H. 1976. Theory of the Firm: Managerial Behavior, Agency Costs and Ownership Structure. Journal of Financial Economics

Kompasiana beyond blogging, https://www.kompasiana.com/wahyu-triono2010/550178a0813311eb18fa845a/moralhazard-bangsa\# diakses pada November 2019

Martha, Diah. 2016. Analisis Anggaran Belanja Daerah Sebelum dan Pada Saat Pemilihan Umum Kepala Daerah (Pemilukada) pada Daerah Non-incumbent di Indonesia. Skripsi. Universitas Lampung

Vicente, Cristina., Rios, A., and Guillamon, M. (2013). Voting Behavior And Budget Stability. Revista de Contabilidad - Spanish Accounting Review, 16 (1), 46-52

Widada. 2015. Analisis Belanja Hibah, Belanja Bantuan Sosial, Belanja Bantuan Keuangan, dan Belanja Modal Selama Dua Periode Kepemimpinan Kepala Daerah di Pulau Jawa 2000-2014. Tesis. Universitas Gadjah Mada

Yuwani, Handayani. 2011. Analisis Rasio Alokasi Belanja Antara Daerah Incumbent dan Daerah Non-Incumbent Sebelum dan pada saat Pemilukada (Studi Kasus di Indonesia). Universitas Diponegoro

Kementrian Keuangan Republik Indonesia https://www.kemenkeu.go.id/publikasi/berita/30-persen-alokasi-apbd2014-diharapkan-untuk-belanja-modal-daerah/ diakses pada Januari 2020 